Erkan Irmak, Eski Köye Yeni Roman: Köy Romaninın Tarihi, Kökeni ve Sonu (1950-1980), İstanbul: İletişim Yayınları, 2018, 332 s.

Değerlendiren: Bilgin Güngör

\title{
Giriş Yerine
}

Köy romanı üzerine Türkiye'deki akademik çalışmaların kısıtlı sayıda oluşu özellikle de araştırmacılar nezdinde bilinen bir gerçektir. Hatta Ramazan Kaplan'ın Cumhuriyet Dönemi Türk Romanında Köy adlı hacimli çalışması dışında ilgili konuda/konularda öne çıkan başka bir kaynağın olmadığı dolayısıyla Türk romanında köyün yansıtılışı, değerlendirilişi veya bir sorunsal olarak ele alınışı noktasında bir "kaynak sıkıntısı" çekildiği söylenebilir. Erkan Irmak'ın yakın zamanlarda yayımlanan ve doktora tezine dayanan Eski Köye Yeni Roman: Köy Romanının Tarihi, Kökeni, Sonu (1950-1980) adlı çalışması, bu bağlamda gerçekten büyük önem arz etmekte. $\mathrm{Bu}$ yazıda; eleştirel bir gözle, Irmak'ın çalışmasındaki artıları ve eksileri veya -daha iyi bir benzetmeyle söylersek- "madalyonun ön ve arka yüzündekiler"i -öne çıkan noktalarıyla- belirtmeye gayret edeceğiz.

\section{“Madalyonun Ön Yüzü”}

Yazının başında, Türkiye'de köy romanlarıyla ile ilgili çalışmaların kısıtlı olduğunu hatta bu hususta Kaplan'ın çalışmasının neredeyse bir "tekel" konumunda bulunduğunu dile getirmiştik. Fakat sorun burada bitmez elbette. Şöyle ki söz konusu çalışmalarda köy romanı üzerine kuramsal açıklamalara pek de kapı aralanmadığı, türsel sınırlara net vurguların yapılmadığı görülür. Köy romanı türünün, mekân olarak köyü içeren veya "bir şekilde" köye temas eden romanları kapsadığına dönük 
kısa bir bildirimde bulunulur ve temel sorunsal, "Bizdeki ilk köy romanı hangisidir?" sorusunun cevabına dönük bir arayış ekseninde kilitlenir. Irmak'ın çalışmasında önem arz eden taraflardan bir başka ifadeyle "madalyonun ön yüzü"nde öne çıkan noktalardan biri tam da burada somutluk kazanır. Irmak, köy romanının kuramsal arka planını ve türsel sınırlarını; çeşitli roman kuramlarını (tabii bu arada Ian Watt, Georg Lukàcs ve Mihail Bahtin gibi isimlerin düşüncelerini), Türk ve dünya edebiyatlarında "köy romanı" veya benzer isimlerle adlandırılan roman türüne ait çeşitli pratikleri göz önünde bulundurarak ele almaya girişir. Bu bağlamda bulunduğu en genel saptama şudur: Dünya edebiyatlarında ve -genel olarak- Türk edebiyatında köye belli ölçülerde temas eden romanlar ile Köy Enstitülü yazarlar tarafından özellikle 1950-1980 arasında ortaya konulan romanlar, gerek içerik gerekse de biçim açısından iki ayrı tür çatısı altında değerlendirilmelidir. Irmak, ilk türü "köy temalı roman", ikinci türü de "köy romanı" olarak adlandırır (s. 34). Böylelikle köy romanını, Türk edebiyatının belli bir dönemine özgü roman türü olarak konumlandırır.

Böyle bir ayrımın akabinde Irmak, köy romanlarının türsel sınırlarını belirleyen çeşitli özellikler saptar. En temel olanını ise -çeşitli edebiyat tarihlerinde "Üç Kemaller” adı altında gruplanan- Yaşar Kemal, Orhan Kemal ve Kemal Tahir'in köy temalı romanlarıyla Enstitülü yazarların romanları arasında bir karşılaştırma yaparak şu şekilde açılar: "Ne var ki 'köy temalı romanlar' denince akla ilk gelen Yaşar Kemal, Orhan Kemal, Kemal Tahir gibi romancılar için köy hemen her seferinde daha büyük bir meseleyi göstermek, açıklamak ya da bir çözüm önerisi sunmak, bir tarihselleştirme veya ideolojik konumlandırmada bulunmak için araçsallaşırken Enstitü mezunu romancıların temel kaygısı, köyü kendi iç dinamikleriyle kaydedip tekil ve dışa kapalı bir bakışla 'aktarmak'tır. Yorumlamaktan ziyade fotoğraflamakla ve dönüştürmek yerine olduğu gibi bırakmakla (elbette dinî dogmaların yerine Kemalizm'in tanımladığı biçimiyle Aydınlanmacı fikirlerin alması şartıyla) ilgilenir ve yetinirler ki bu da aralarında türsel bir çıkış farklılığı olduğuna inandığım köy romanlarını, köy temalı romanlardan ayıran en temel özelliktir" (ss. 27-28). En temel yani köy hayatının kurguda amaçsallaştırılması özelliği dışında köy romanlarının diğer özelliklerini Irmak, çeşitli örnekler doğrultusunda ele alır. Bunlar arasında "yaşlı bilge"lerin varlığı, karakterlerin varoluşsal kaygıdan muaflığı, mekân-zaman birlikteliği, olayların "dışsal” bir durumdan kaynaklanması ve düzenin yeniden sağlanmaya çalışılması etrafında zuhur edişi, "din”in aydınlanma değerleri adına net bir biçimde hedefe konulması özellikle öne çıkar (ss. 179-290).

Irmak'ın köy temalı romandan ayrılan köy romanın türsel özelliklerini örnekler üzerinden vermesi şüphesiz söz konusu örnekleri ve elbette bunları ortaya çıkaran 
temelleri sistemli ve derinlikli bir şekilde ele alışının neticesidir ki "madalyonun ön yüzü"nde beliren bir başka önemli noktayı da burada aramak gerekir. Köy ile ilgili romanlara dönük çalışmaların kısıtlı oluşuna paralel bir şekilde Enstitülü yazarların eserleri söz konusu olduğunda akademik anlamda bir suskunluğun vaki olduğu barizdir (elbette bunun ideolojik ve yerleşik "sanat rejimi” üzerinden bir açıklaması yapılabilir). Irmak, bu bağlamda da bir boşluğu doldurarak Enstitülü yazarlarla ortaya çıkan roman ve hatta edebiyat türünü (köy edebiyatı) bizzat Enstitü'nün kuruluş ve hedeflerindeki epistemolojik derinliği ve Türkiye'nin 1950-1980 yılları arasındaki sosyolojik dönüşümünü göz önünde bulundurarak ele almaktadır. Bu bağlamda Irmak, 1940’ların ses getiren eğitim kurumlarından olan ve "sui generis" konumda bulunan Köy Enstitüleri'nin ilerleyen yıllarda Türk edebiyatının hâkim kollarından birini temsil edecek bir köy edebiyatı yaratı̆̆ını ve bu edebiyatın, ilk örneği 1950'de Mahmut Makal'ın kitap olarak yayımlanan Bizim Köy'ü olan “köy not"u türüyle başladığını daha sonrasında ise başta Fakir Baykurt olmak üzere pek çok Enstitülü yazarın romanlarıyla geliştiğini ancak özellikle de 1980’lere doğru Türkiye'nin köyden şehre doğru bir istikamet gösteren demografik değişiminin ve söz konusu yazarların toplumcu edebiyata eklenişinin neticesinde köy edebiyatının hâliyle de köy romanının ortadan kalktığını tespite yönelir.

"Madalyonun ön yüzü"nde önem arz eden bir başka nokta olarak ise dilin kullanılış biçimini ele alabiliriz. Bilindiği üzere Türkiye'deki akademik söylem, büyük oranda, dilin geniş zaman kipi çerçevesinde ve pek de akıcı olmayan bir biçimde kullanımına dayanır (son dönemlerde çeşitli akademik ortamlarda tartışıldığına şahit olduğumuz "okunmama" sorununun bir nedeni akademik metinlerin özellikle "yağmacı dergi"ler -hatta "yağmacı yayınevleri"- vasıtasıyla sayıca artması ve niteliksizleşmesi ise diğer bir nedeni söz konusu akademik yazım anlayışıdır denilebilir). Ancak Irmak görece farklı bir yol izleyerek yer yer çeşitli kip kullanımlarına kapı aralayarak yer yer de mizahiliğe başvurarak akademik söylemi kısmen de olsa farklı söylem biçimlerinin imkânlarıyla buluşturmakta ve böylelikle dilsel monotonluğu devre dışı bırakmaktadır. Bu bağlamda bir örnek olarak eserin "giriş" mahiyetindeki "Giriş Mecburi: Türkçe Romanda Köy” kısmında, Irmak'1n arkadaşlarıyla birlikte Orhan Koçak ile yaptığ1 2010 tarihli röportaj “macera”sını anlattığı satırlara bakılabilir. Bu monotonluktan uzak, mizahilikle beliren satırların benzerlerini çoğu akademik çalışmada bulamayacağımız barizdir: "Amatör bir heyecanla arkadaşlarımla birlikte yayımladığımız yeniyazı dergisi için Orhan Koçak’la 2010 yılında bir söyleşi yapmıştım. 'Heyecan' ve 'amatör' kelimelerini vurguluyorum çünkü o sayının odağına aldığımız Koçak'ın yazdığı neredeyse bütün yazıları kütüphanelerden toplamış, okumuş, not almış ve ne kadar anladığım şüpheli olan bu sert ve 
girift yazılardan yola çıkan kapsamlı sorular hazırlamıştım. Heyecan kısmı burada devreye giriyor sanırım zira o mülakatta belki yazarının bile unuttuğu yıllar öncesinin makalelerinde kalmış, kimsenin dikkat etmediği cümlelerden hız alan sorular da yöneltmiştim, seneler içinde Koçak'in eğildiği meseleleri toparlayan biraz da 'hesap soran' bir edaya sahip bol yorumlu sorular da. Doğrusu o günkü hazırlığımın hâlâ vasatın altında olmadığını düşünüyorum ama söyleşinin seyrine bakıldığında zaman zaman fazla uzun ve yersiz zorlamalarla söz aldığımı da kabul etmem gerek. Neyse ki Koçak, cevaplarının arasına sıkıştırdığı ve yazılarında da sık sık kullandığı ironik üslubuyla hak ettiğim yanıtları benden esirgememiş, hem ciddiyetle konular1 tartışmış hem de 'gençliğimi' tatlı tatlı bana hatırlatmıştı (nitekim amatörlük de sanırım burada ortaya çıkmıştı)" (s. 22).

Buraya kadar Irmak'ın çalışmasının "olumlu” gördüğümüz yanlarını ya da -yazı boyunca kullandığımız ve kullanacağımız benzetmeden hareketle söylersek- "madalyonun ön yüzü”nde öne çıkanları gösterdik. Peki “arka yüz”de öne çıkanlar?

\section{“Madalyonun Arka Yüzü”}

Irmak'ın köy temalı romanla köy romanı arasında bir ayrımda bulunduğunu, ikincisini Türk edebiyatının belli bir döneminde ortaya çıkan ve Enstitülü yazarların romanlarını imleyen özgün bir tür olarak konumlandırdığını yukarıda belirtmiştik. Fakat Irmak, çalışmasının ana konusu olan köy romanı hususunda örneklerin hemen hepsini Fakir Baykurt'un romanlarından seçmiş ve çalışmayı bir anlamda Baykurt romancılığına indirgemiştir ki "madalyonun arka yüzü”nde öne çıkan noktalardan birisi bu çerçevede somutluk kazanır. Eser incelemelerine geçmeden evvel "bölüm boyunca Baykurt'un farklı romanlarından farklı noktalarda yararlanırken yeri geldikçe diğer köy romancılarından" (s. 182) da bahsedeceğini belirtmiştir Irmak, ancak incelemeler sırasında "diğer köy romancılarını" bulmak pek de mümkün değildir. Dolayısıyla incelemeler dikkate alınınca, çalışmanın başlğınndaki "Köy Romanın Tarihi, Kökeni ve Sonu" ifadesinin söz konusu çalışmaya "birkaç beden büyük" geldiği görülmektedir. Bu durumun ayrıca köy temalı roman ile köy romanı arasında Irmak'ın yaptığı ayrımı ve betimlediği türsel karşıtlıkları tartışmalı kıldığı da söylenebilir.

Şüphesiz Baykurt’un romanlarının diğer Enstitülü yazarların romanları arasında öne çıktığını ve bu hususta en yetkin olanları temsil ettiği bir gerçektir. Hâliyle köy romanına dönük bir çalışmada, Baykurt'un romanlarının merkeze alınması gayet doğaldır ancak böyle bir tercih, diğer Enstitülü yazarların romanlarını görmezden gelmeyi bir ön kabul olarak konumlandırmak anlamına gelmez. Gelmemelidir 
de. Çünkü böyle bir durum, Baykurt'un romanlarının özelliklerinin köy romanlarının geneline "giydirilmesi” sorununu ortaya çıkarır ki Irmak’ın çalışmasının bu sorundan muaf olmadığı söylenebilir.

Belirtmek gerekir ki Irmak, benzer bir hatayı, köy edebiyatının ilk metinleri olarak gördüğü "köy notu” türünü ele alırken de yapar. Evet Mahmut Makal'ın Bizim Köy'ü, köy notu türünün en önde geleni ve Irmak'ın da işaret ettiği gibi köy edebiyatının "kurucu metni"dir (s. 27). Ancak çalışmada diğer Enstitülü yazarların köy notlarının göz ardı edilerek konu bağlamında sadece Bizim Köy’e başvurulması ve bu eser üzerinden köy notlarına dönük genellemelerde bulunulması, kabul edilebilir bir tutum olmaktan uzaktır.

"Madalyonun arka yüzü”nde öne çıkan bir diğer noktanın da çalışmanın "kurgu"sunu zayıflatan, sistematikliğine zarar veren bir kısım ayrıntılar etrafında düğümlendiğini dile getirebiliriz. Yukarıda belirtmiştik: Irmak, köyden bahseden romanları, eleştiri tarihimizde görülmedik bir şekilde kuramsal ve türsel açıdan sorunsallaştırır ve bu bağlamda çeşitli kuramcıların düşüncelerinden ve ilgili roman pratiklerinden hareket eder. Ancak bu çaba zaman zaman ana konuyla dolaysız yoldan dahi bağlantısı olmayan ayrıntıların da çalışmaya dâhil olmasına sebebiyet vermiştir. Sözgelimi Irmak'ın roman ile patates arasında benzerlik kurduğu "Roman ve Patates" kısmının -oldukça ilginç bilgileri ve çıkarımları kapsamış olsa da- çalışmanın ana konusundan fazlasıyla bağımsız olduğu düşünülebilir. Yine bir önceki kısımda yani Irmak'ın çeşitli roman kuramlarını ele aldığı "Üç Tarz-1 Roman" kısmında ana konuyla ilgili olan, onu destekleyen bazı bilgiler ve çıkarımlar (sözgelimi modernite ile roman arasındaki ilişkiye dair açıklamalar) bulunsa da aksi yöndekilerin yoğunluğu da vakidir (sözgelimi "evrimci” roman kuramlarına dair açıklamalar). İşte bu tür ayrıntıların okuma esnasında akıllarda "Pek güzel ama bunun köy romanı ile ilgisi nedir?” sorusunu doğurduğu söylenebilir.

\section{Son Dikkatler}

Irmak'ın çalışmasının artı ve eksilerini yani "madalyonun ön ve arka yüzlerini” idrak ettikten sonra bizde kalan "nihai düşünce" nedir [bu soruyu, çalışmasının "Sonuç” kısmında, Irmak’ın Enstitülü yazarların kendisinde bıraktığ1 "nihai duygu”yu açıklamasından (s. 309) ilhamla soruyorum]? Şöyle cevaplayabiliriz: Artılarıyla/ eksileriyle Irmak'ın çalışması, ufuk açıcıdır ayrıca çoğunlukla az veya yanlış bildiğimiz konuları yeniden düşünmeye sevk edicidir. Güncel akademik çalışmaların pek çoğunda -maalesef- göremediğimiz nitelikler de bunlar değil midir? 
